\title{
ĐĂC ĐIỂM LÂM SÀNG ĐAU VÙNG Cổ GÁY DO THOÁI HÓA CộT SỐNG TRỀN BỆNH NHÂN ĐIỀU TRI TẠI BỆNH VIỆN CHÂM CỨU TRUNG ƯO'NG
}

\section{TÓM TẮT}

Mục tiêu: Đánh giá tình trang đau vùng cổ gáy do thoái hóa cô̂t sống và một số yếu tố liên quan. Đối tượng và phương pháp: 60 bệnh nhân tuổi từ $30-$ 75 ,được chẩn đoán đau vùng cổ gáy do thoái hóa cột sống, điều trị tại Bệnh viện Châm cứu Trung ương từ 08/2018- 04/2019, không phân biệt giới tính, nghề nghiệp, tình nguyện tham gia nghiên cứu. Đánh giá đặc điểm chung các đối tượng nghiên cứu, mức độ đau theo thang điểm VAS, đánh giá một số yếu tố liên quan tới đau, mức độ hạn chế tầm vận động cột sống cổ và ảnh hưởng chức năng sinh hoạt hàng ngày theo NPQ. Kết quả: Tuổi mắc bệnh trung bình 56,95 \pm 11,01(năm) với 38,3\%mắc bệnh trên 6 tháng. Đau phần nhiều khởi phát mang tính chất từ từ, âm ỉ và không liên tuc. Đau mức độ vừa và năng chiếm $93,3 \%$. Đau có liên quan tới các yếu tố vận động và yếu tố thay đổi thời tiết. Đau cũng là nhân tố gầy han chế tầm vận động cột sống cổ với $94,3 \%$ hạn chế ở mức độ ít và trung bình, 90\%ảnh hưởng chức năng sinh hoạt hàng ngày ở mức trung bình và ảnh hưởng nhiều với điểm NPQ trung bình là 19,4 $\pm 2,8$ (điểm). Kết luận: Đau vùng cổ gáy do thoái hóa cột sông gây ảnh hưởng nhiều tới chất lượng cuộc sống, lao động và sinh hoạt của người bệnh. Bệnh liên quan tới yếu tố tuổi, nghề nghiệp, vận động và̀ yếu tố thay đổi thời tiết.

Tư khóa: Đau, thoái hóa cột sống cô.

\section{SUMMARY}

\section{ASSESSMENT OF PATIENTSWITH CERVICAL SPONDYLOSIS AT NATIONAL HOSPITAL OF ACUPUNCTURE}

Objectives: To evaluate the cervical spondylosisand some related factors. Subjects and method: 60 volunteered patients ages from 30-75, which were diagnosed with cervical sondylosis, were getting treatment at National Hospital of Acupuncture from 2018August to 2019April; irrespective of occupation, gender. Generalizing the characterization of the patients, the pain score on the VAS scale, assess a number of factors related to pain, degree of range of motion limited cervical spine and affects daily functioning according to NPQ. Results: The age average is $50.5 \pm 13.8$ (years) with $38,3 \%$ patients had the duration of illness over 6 months. Pain is mainly gradual, dull, and intermittent. Moderate and severe pain made up to $93.3 \%$. The disease is strongly associated with movement and climate change

${ }^{1}$ Bệnh viện Châm cứu Trung ương,

2 Viện Y họ cổ truyền Quân đồi

Chịu trách nhiệm chính: Nguyễn Vinh Quốc

Email: quocnguyenvinh@gmail.com

Ngày nhận bài: 29/4/2021

Ngày phản biên khoa học: 25/5/2021

Ngày duyệt bài: 18/6/2021

\section{Nguyễn Đức Minh ${ }^{1}$, Nguyễn Vinh Quốc ${ }^{2}$}

factors. It's also a factor that limits cervical spine range with $94.3 \%$ limited to low and moderate levels, $90 \%$ have moderate and large influence on daily function with the average NPQ score was $19.4 \pm 2.8$ (points). Conclusion: Cervical spondylosis greatly affects the quality of work and life of patients. It were related to age, professional characteristics, movement and climate change factors.

Keywords: Pain, cervical spondylosis.

\section{I. ĐẶT VẤN ĐỀ}

Đau vùng cổ gáy (hội chứng cổ vai cánh tay, hội chứng vai tay) do thoái hóa cột sống là bệnh lý thường gặp với biểu hiện lâm sàng cơ bản là đau vùng cổ vai lan xuống cánh tay, cẳng tay kèm rối loan cảm giác, vận động tại vùng chi phối của rể dây thần kinh cột sống cổ [1],[2]. Bệnh thường gặp ở đối tượng đang trong độ tuổi lao động, mang tích chất dai dẳng, dễ tái phát, tuy ít nguy hiểm tới tính mạng nhưng gây ảnh hưởng nhiêuu tới sức khỏe, suy giảm khả năng học tập, lao động cũng như gây ảnh hưởng không tốt tới chất lượng cuộc sống của người bệnh[1], [3], [4], [5]... Do vậy điều trị và điều trị dự phòng bệnh lý này là yểu cầu cấp thiết đối với đời sống xã hội nhằm nhanh chóng giải phóng người bệnh khỏi tình trạng đau, tránh kéo dài trở thành đau mạn tính, trả người bệnh về với công việc và sinh hoạt hàng ngày.

Là cơ sở điều trị chuyên ngành $Y$ hoc cổ truyền, Bệnh viện Châm cứu Trung ương đã tiếp nhận điều trị nhiều bệnh nhân đau vùng cổ gáy do thoái hóa cột sống. Để có cơ sở xây dựng phác đồ điều trị phù hợp, hiệu quả, góp phần mang lại sức khỏe cho người bệnh. Nghiên cứu được thực hiện nhằm mục tiêu đánh giá tình trạng đau vùng cổ gáy do thoái hóa cột sống trển bệnh nhân khám và điều trị tại Bệnh viện Châm cứu Trung ương.

\section{II. ĐỐI TƯỢNG VÀ PHƯƠNG PHÁP NGHIÊN CỨU}

2.1. Đối tượng nghiên cứu. 60 bệnh nhân (BN) tuổi 30-75, không phân biệt giới tính, nghề nghiệp, tình nguyện tham gia nghiên cứuđược chẩn đoán đau vùng cổ gáy do thoái hóa cột sống[1], [2], mã ICD M54.2[6]. Điều trị tại Bệnh viện Châm cứu Trung ương/Bộ $Y$ tế từ tháng 08/2018- tháng 04/2019. Không đưa vào nghiên cứu những trường hợp ung thư, chấn thương, dị dạng cột sống, bệnh lý ngoài cột sống gây đau.

2.2. Phương pháp nghiên cứu. Nghiên 
cứu mô tả, phân tích, tổng hợp số liệu qua hồ sơ bệnh án BN đang khám chữa bệnh tại Bệnh viện Châm cứu Trung ương/Bộ Y tế.

\subsection{Chỉ tiêu theo dồi và đánh giá}

- Đặc điểm chung các BN nghiên cứu: Tuổi, giới tính, nghề nghiệp, thời gian mắc bệnh, đặc điểm tổn thương trên phim Xquang quy ước.

- Đánh giá các đặc điểm đau (tính chất khởi phát; cường độ đau; tính chất đau; yếu tố liên quan). Mức độ đau theo thang điểm VAS (Visual Analog Scales), phân thành các mức độ: không đau, đau nhẹ, đau vừa, đau nặng và rất đau[1].

- Đánh giá tầm vận động cột sống cổ bằng thước đo nhân trắc học (đo độ gấp, ngửa, nghiêng, xoay). Phân thành các mức độ không hạn chế; hạn chế ít; hạn chế trung bình; hạn chế nhiều;hạn chế rất nhiều[1].

-Đánh giá mức độ ảnh hưởng chức năng sinh hoạt hàng ngày theo thang điểm NPQ (Northwick Park Neck Pain Questionaire), xếp thành các mức độ không ảnh hưởng; ảnh hưởng ít; ảnh hưởng trung bình; ảnh hưởng nhiều; ảnh hưởng rất nhiều[1].

2.4. Xử lý số liệu. Số liệu thu thập được xử lý bằng phần mềm thống kê y học SPSS 16.0 for Windows. Sử dụng các thuật toán tính tỷ lệ phần trăm, tính số trung bình, độ lệch chuẩn.

\section{KẾT QUẢ NGHIÊN CỨU}

\section{1. Đặc điểm chung các bệnh nhân} nghiên cứu

Bảng 1. Đặc điểm chung các bệnh nhân nghiên cứu

\begin{tabular}{|c|c|c|c|}
\hline \multicolumn{2}{|r|}{ Chỉ tiêu } & \multirow{2}{*}{$\begin{array}{c}\begin{array}{c}\text { Số } \\
\text { lượng }\end{array} \\
05\end{array}$} & \multirow{2}{*}{$\begin{array}{c}\begin{array}{c}\text { Tỷ lệ } \\
\text { \% }\end{array} \\
8,3\end{array}$} \\
\hline \multirow{4}{*}{ Tuổi } & $<40$ & & \\
\hline & $40-60$ & 32 & 53,4 \\
\hline & $>60$ & 23 & 38,3 \\
\hline & \multicolumn{3}{|c|}{$\begin{array}{l}\text { Tuối trung bình (năm; } X \pm S D) \text { : } \\
56,95 \pm 11,01\end{array}$} \\
\hline \multirow{2}{*}{ Giới tính } & Nam & 29 & 48,3 \\
\hline & Nũ̃ & 31 & 51,7 \\
\hline \multirow{3}{*}{$\begin{array}{c}\text { Nghề } \\
\text { nghiệp }\end{array}$} & Lao động trí óc & 41 & 68,3 \\
\hline & Lao động phố thông & 19 & 31,7 \\
\hline & $<1$ tháng & 19 & 31,7 \\
\hline \multirow{3}{*}{$\begin{array}{c}\text { Thời gian } \\
\text { mắc } \\
\text { bệnh }\end{array}$} & $1-<3$ tháng & 11 & 18,3 \\
\hline & $3-<6$ tháng & 7 & 11,7 \\
\hline & $\geq 6$ tháng & 23 & 38,3 \\
\hline \multirow{4}{*}{$\begin{array}{l}\text { Dặc điểm } \\
\text { phim } \\
\text { Xquang } \\
\text { quy ước }\end{array}$} & $\begin{array}{l}\text { Thay đối đường } \\
\text { cong sinh lý }\end{array}$ & 9 & 15,0 \\
\hline & $\begin{array}{l}\text { Hẹp khe gian đốt } \\
\text { sống }\end{array}$ & 25 & 41,7 \\
\hline & Hẹp lồ ghép & 31 & 51,7 \\
\hline & Gai xương, mỏ & 37 & 61,7 \\
\hline
\end{tabular}

\section{\begin{tabular}{|c|c|c|}
\hline xương & & \\
\hline Đặc xương dưới sụn & 57 & 95,0 \\
\hline
\end{tabular}}

Tuổi trung bình các đối tượng nghiên cứu là $56,95 \pm 11,01$ (năm), trong đó độ tuổi trên40 chiếm tỷ lệ cao $(91,7 \%)$. Về giới tính, nữ giới chiếm $51,7 \%$. Phần lớn đối tượng đau vùng cổ gáy do thoái hóa cột sống là lao động trí óc $(68,3 \%)$. BN có thời gian mắc bệnh trền 6 tháng chiếm tỳ lệ cao (38,3\%). Tổn thương hay gặp nhất trên phim Xquang cột sống cổ quy ước là đặc xương dưới sụn (95\%); gai xương, mỏ xương $(61,7 \%)$ và hẹp lố ghép $(51,7 \%)$.

3.2. Đặc điểm đau, mức độ hạn chế tâm vận động cột sống cổ và kết quả đánh giá ảnh hưởng chức năng sinh hoạt hàng ngày

Bảng 2. Một số đặc điểm lầm sàng liên quan dau

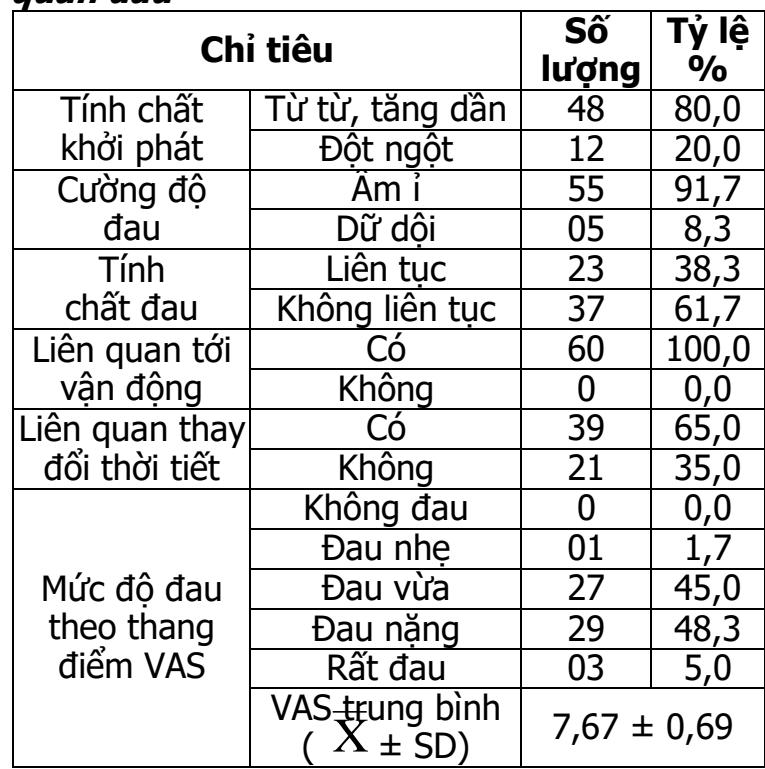

Bệnh khởi phát mang tính chất từ từ, tăng dần $(80 \%)$, đau âm ỉ $(91,7 \%)$ và không liên tục $(61,7 \%) .100 \%$ đau có liên quan tới vận động và $65 \%$ liên quan tới thay đổi thời tiết. Tất cả các BN tới khám và điều trị đều biểu hiên đau ở các mức độ khác nhau trong đó đau vừa và nă̆ng chiếm tỷ lệ cao( $93,3 \%)$ vớiđiểm VAS trung bình là 7,67 $\pm 0,69$ (điểm).

Bảng 3. Mức độ ảnh hưởng chức năng sinh hoạt theo thang điểm NPQ

\begin{tabular}{|c|c|c|}
\hline Mức độ ảnh hưởng & $\begin{array}{c}\text { Số } \\
\text { lượng }\end{array}$ & $\begin{array}{c}\text { Tỉ lệ } \\
\text { \%o }\end{array}$ \\
\hline Không ảnh hưởng & 0 & 0,0 \\
\hline Annh hưởng ít & 04 & 6,7 \\
\hline Ánh hưởng trung bình & 26 & 43,3 \\
\hline Ánh hưởng nhiều & 28 & 46,7 \\
\hline Anh hưởng rất nhiều & 02 & 3,3 \\
\hline Điếm NPQ trung bình $\left(\bar{X}_{ \pm S D}\right)$ & \multicolumn{2}{|c|}{$19,4 \pm 2,8$} \\
\hline
\end{tabular}


Các BN đau vùng cổ gáy do thoái hóa cột sống có mức độ ảnh hưởng tới chức năng sinh hoạt hàng ngày được đánh giá theo thang điểm NPQ đa số ở mức trung bình và mức ảnh hưởng nhiều $(90 \%)$ với điểm NPQ trung bình là 19,4 \pm 2,8 (điểm).

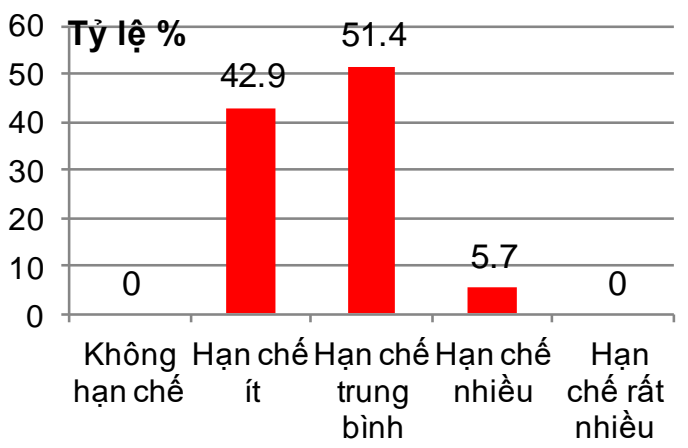

Mức độ hạn chế

\section{Biểu đồ 1. Mức độ hạn chế tầm vận động cột sống cồ}

Đa số các trường hợp $\mathrm{BN}$ hạn chế tầm vận động cột sống cổ ở mức độ ít và trung bình với tỳ lệ tương ứng là $42,9 \%$ và $51,4 \%$. Không có BN không bị hạn chế vận động cột sống cổ hoặc hạn chế ở mức độ rất nhiều.

\section{BÀN LUÂN}

4.1.Về đặc điểm chung các đối tượng nghiên cứu. Tuổi trung bình của các đối tượng trong nghiên cứu là $56,95 \pm 11,01$ trong đó $53,4 \%$ có độ tuổi từ 40 tới 60 cho thấy đau vùng cố gáy do thoái hóa cột sống thường gặp ở những đối tượng đang trong độ tuổi lao động, kết quả này phù hợp với nhận định của nhiều tác giả [3], [4], [5]... Điều này cho đau vùng cổ gáy do thoái hóa cột sống có ảnh hưởng nhiều tới hoạt động sản xuất, kinh tế, xã hội... và do vậy đang trở thành mối quan tâm nghiên cứu của các nhà khoa học, đặc biệt trong lĩnh vực y học. Theo Y học cổ truyền, ở độ tuổi trên 40 chính khí của cơ thể con người bắt đầu giảm sút, thận khí kém dần, thiên quí kiệt, công năng của các tạng phủ có chiều hướng suy giảm do đó ở lứa tuổi này bệnh tật dễ phát sinh[2],[7]. Điều cần lưu ý trong nghiển cứu là tỷ lệ $\mathrm{BN}$ dưới 40 tuổi mắc bệnh chiếm $8,3 \%$, chứng tỏ đau vùng cổ gáy do thoái hóa cột sống có xu hướng trẻ hóa, do vậy điều trị và điều trị dự phòng đối với bệnh lý này là vấn đề cần được quan tâm.

Về giới, $51,7 \%$ đối tượng trong nghiên cứu là nữ giới, phù hợp với kết quả nghiên cứu của một số tác giả[3], [4], [5]. Các nghiên cứu đều cho rằng tỷ lệ nữ đau vùng cổ gáy do thoái hóa cột sốngnhiều hơn nam do sự thay đổi hormon, đặc biệt sự thiếu hụt estrogen sau mãn kinh, mặt khác cũng có thể do phụ nữ có ý thức quan tâm tới sức khỏe bản thân hơn nên tới khám và điều trị ngay khi mới xuất hiện triệu chứng bệnh[1], [3], [4], [5].

Về nghề nghiệp, Hồ Hữu Lương[1] cho rằng tư thế lao đônng cúi cổ lâu với các động tác đơn điệu lặp đi lặp lại của đầu, vùng cổ gáy luôn phải chịu một trọng lực thường xuyên kéo dài hàng giờ, hàng ngày, thói quen ít vận động... Quá trình này lặp đi lặp lại kéo dài gây hạn chế quá trình trao đổi chất, hạn chế lưu lượng tuần hoàn tại chỗ, thói quen vận động cột sống cổ đột ngột dễ gây ra các vi chấn thương làm cho mô xương, cơ, dây chằng bị biến đổi và dễ bi thoái hóa dẫn tới sự gia tăng của thoái hóa cột sônng. Kết quả nghiển cứu của chúng tôi nhận thấy đối tượng mắc bệnh là lao động trí óc chiếm tỷ lệ cao $(68,3 \%)$, tuy nhiên cũng gặp ở 31,7\% đối tượng lao động phổ thông, phù hợp với nhận định của nhiều tác giả: đau vùng cổ gáy do thoái hóa cột sống là một bệnh mạn tính xảy ra ở mọi thành phần của xã hội[1], [3], [4], [5]...

Trong đau vùng cổ gáy do thoái hóa cột sống, triệu chứng lâm sàng nhiều khi không điển hình như các bệnh lý mang tính chất cấp tính. Nhiều BN chỉ có triệu chứng nhẹ, không trầm trọng nên dễ bỏ qua. Nhiều BN đau cổ gáy nhiều nắm, mới đầu chỉ là cảm giác mỏi vùng cổ, sau đó xuất hiện đau và mỏi sau làm việc, sau vận động, lâu dần tình trang đau mỏi xuất hiền thường xuyên nên cơ thể cũng thích ứng dần với trạng thái đau đó. Do vậy thường cố chịu đựng mà không đến các cơ sở y tế để được chăm sóc hoăcc tự điều trị, bênh có thể tự khỏi hoăc chuyển thành mạn tính, khi gặp tác nhân gầy bênh sẽ chuyển thành cấp tính. Chỉ khi có ảnh hưởng thực sự đến khả năng lao động, ảnh hưởng đến sinh hoat hàng ngày bênh nhân mới đến cơ sở y tế để điều trị:[1]. Nghiên cứu của chúng tôi cho thấy có tới $38,3 \%$ BN có thời gian mắc bệnh trên 6 tháng, phù hợp với nhận định của Lê Thị Diêuu Hằng (2014), Nguyễn Vinh Quốc (2019): trền 1/3 số BN tới khám khi đã xuất hiện đau trên 6 tháng[3], [4], [5]. Điều này cũng cho thây cho thây đau vùng cổ gáy do thoái hóa cột sốnglà một bênh lý mang tính chất mạn tính dai dẳng, gây ảnh hưởng nhiêuu tới chất lượng cuộc sống của người bệnh[1]. Kết quả này cũng cho thây thực trạng đáng lo ngại là đau vùng cổ gáy do thoái hóa cột sốngchưa thực sự nhận được quan tâm đúng mức của bản thân người bệnh, do vậy việc tăng cường giáo dục cộng đồng đối 
với bệnh lý này là hết sức cần thiết và có ý nghĩa.

Kết quả nghiên cứu cho thấy tổn thương hay gặp nhất trên phim Xquang cột sống cổ quy ước là đặc xương dưới sụn $(95 \%)$; gai xương, mỏ xương $(61,7 \%)$ và hep lỗ ghép $(51,7 \%)$. Thay đổi đường cong sinh lý chiếm tỷ lệ thấp nhất (15\%). Trên thực tế điều trị, nhiều trường hợp không nhận thấy sự tương đồng giữa các triệu chứng lâm sàng với mức độ tổn thương trên phim Xquang. Chính vì vậy để chẩn đoán xác định đau vùng cổ gáy do thoái hóa cột sống cần kết hợp linh hoạt giữa triệu chứng lâm sàng và hình ảnh tổn thương trên phim chụp Xquang[1], [4]

4.2. Về đặc điểm đau, mức độ hạn chế tâm vận động cột sống cổ và kêt quả đánh giá ảnh hưởng chức năng sinh hoạt hàng ngày. Đau là một cơ chế bảo vệ cơ thể, là dấu hiệu cảnh báo về những bất ổn đối với sức khoẻ con người. Cảm giác đau xuất hiện tại một vị trí nào đó khi bi tổn thương taoo nên một đáp ứng nhằm loại trừ tác nhân gây đau[1]. Đau cổ gáy cũng là triệu chứng chính khiến bệnh nhân phải nhập viện điều trị. Đau sẽ gây phản ứng co cơ tại chỗ, khi cơ co thì lai đau tăng, đây là vòng xoắn bệnh lý[1]. Đau kết hợp tình trạng co cứng khối cớ cạnh sống sẽ gây hạn chế tầm vận động cột sống vùng cố gáy, đặc biệt ảnh hưởng tới độ giãn cột sống vùng cổ gáy. Theo lý luận Y học cổ truyền, nguyên nhân chính của bệnh là do chính khí hư suy, hoặc do không kiên trì tập luyện nâng cao sức khoẻ, hoặc phòng dục quá độ, hoặc do sau quá trình mắc bệnh... làm cho khí huyết hư nhược, tấu lý sơ hở, vệ khí suy giảm, tạo điều kiện cho ngoại tà phong, hàn, thấp thừa lúc cơ thể hư nhược mà xâm nhập vào, lưu trú ở cơ nhục, kinh lạc làm cho khí huyết vận hành không thông, bất thông tất thống mà gây ra đau[2],[4],[7]. Ngoài ra, các sản vật sinh ra từ quá trình bệnh tật như huyết ứ, đàm trọc có thể trực tiếp hoặc gián tiếp tác động tới cơ thể dẫn tới trở trệ kinh mạch, khí vận hành không được thông suốt (khí trệ), khí trệ huyết ứ làm cho mạch lạc vận hành gặp trở ngại, các chấn thương gây ra tình trạng ứ huyết, tại chỗ không được nuôi dưỡng đây đủ, dinh vệ mất đi sự điều hoà, tạo điều kiện để ngoại tà xâm nhẩp mà phát sinh đau[2],[5],[7]. Kết quả nghiên cứu cho thấy tất cả các đối tượng đều biểu hiện đau ở các mức độ khác nhau trong đó đau vừa và nặng chiếm tỷ lệ cao $(93,3 \%)$ với điểm VAS trung bình là 7,67 $\pm 0,69$ (điểm). Đa phần đau vùng cổ gáy do thoái hóa cột sông khởi phát mang tính chất từ từ, tăng dân $(80 \%)$, đau âm ỉ $(91,7 \%)$ và không liên tục $(61,7 \%)$, phù hợp với cơ sở lý luận của Y học hiện đại cũng như Y học cổ truyền đối với bệnh lý này [1], [7].

Kết quả nghiên cứu cho thấy tất cả các đối tượng đều nhận thấy tình trạng đau có liên quan tới vận động, phù hợp với nhận định của nhiều nghiển cứu về ảnh hưởng của lao động đối với thoái hóa khớp nói chung trong đó có thoái hóa cột sống cổ: quá trình lao động tùy theo mức độ nặng hay nhẹ đều tạo những áp lực lên hệ cơ xương - khớp dẫn tới đau [1], [3], [4], [5].

Trong thoái hóa cột sông cố, đau cũng là nhân tố gây co rút các cơ cạnh sống, sự co kéo các tổ chức liên kết bao gồm cân cơ, dây chằng, bao khớp... đã gây ảnh hưởng nhiều tới tầm vận động cột sống cổ, ảnh hưởng tới chất lượng cuộc sống, lao động và sinh hoạt của người bệnh[3], [4], [5]. Kết quả nghiên cứu cho thấy tỷ lệ BN hạn chế tầm vận động cột sống cổ ở mức độ ít và trung bình chiếm tới $94,3 \%$. Có lẽ do đặc thù tiếp nhận đối tượng điều trị của một bênh viện chuyên ngành $Y$ học cổ truyền nên trong nghiên cứu tỷ lệ BN hạn chế tầm vận động cột sống cổ ở mức độ nhiều là không lớn $(5,7 \%)$ và không có $B N$ hạn chế ở mức độ rất nhiêu. Có tới $90 \%$ đối tượng trong nghiên cứu được đánh giá chức năng sinh hoạt hàng ngày theo thang điểm NPQ ở mức ảnh hưởng trung bình và mức ảnh hưởng nhiều với điểm NPQ trung bình là $19,4 \pm 2,8$ (điểm). Do vây việc giải quyết nhanh chóng và có hiệu quả đối với triệu chứng đau trong bệnh lý này là vấn đề đầu tiên người thây thuốc cần ưu tiên thực hiện[1], [3], [4], [5].

\section{KẾT LUÂ̂N}

- Đau vùng cổ gáy do thoái hóa cột sống là bệnh lý gặp nhiều ở nữ giới. Tuổi càng lớn thì tỷ lệ mắc càng cao, tuổi trung bình $56,95 \pm 11,01$. Tổn thương thường gặp trên phim Xquang quy ước là đặc xương dưới sụn, gai xương, mỏ xương và hẹp lỗ ghép. Bệnh có có liên quan tớiđặc điểm nghề nghiệp, yếu tố vận độngvà yếu tố thay đổi thời tiết.

- Đau vùng cổ gáy do thoái hóa cột sống gây ảnh hưởng nhiều tới tầm vận động cột sống cổ, ảnh hưởng tới chất lượng cuộc sống, lao động và sinh hoạt hàng ngày của người bệnh.

\section{TÀI LIỆU THAM KHẢO}

1. Nguyễn Văn Thông (2011). Bệnh lý cột sống cổ, NXB Thanh niên, Hà Nối.

2. Bộ Y tế (2020). Hội chứng cổ vai cánh tay. "Hưướng dẫn chẩn đoán và điêu trị bệnh theo y hoc cổ truyên, kết hợp y học cổ truyền với y hoc hiển đai". Ban hành kèm theo Quyết đinh số 5013/QĐiBY̛T ngày 01/12/2020 của Bộ trưởng Bộ $Y$ tế, tập I, NXB Y học, Hà Nội, 37-43. 
3. Lê Thị Diệu Hằng, Lại Thanh Hiên (2014). Đánh giá tác dụng điều trị thoái hóa cột sống cổ bằng mãng điên châm kết hợp bài thuốc quyên tý thang. Tạp chí nghiên cứu Y̛ dược học cổ truyền Việt Nam, 40, 54-60.

4. Nguyến Tuyết Trang, Đào Thị Phương (2016). Hiệu quả cúa phương pháp điện châm và cấy chì catgut trong điều trị đau vai gáy do thoái hóa cột sống çổ. Tapp chí nghiên cứu Y học, 103 (5), 17-23.

5. Nguyển Vinh Quốc, Nguyền Đứć Minh (2019). Hiệu quả điều trị đau cổ gáy do thoái hóa cột sống cổ bằng điện châm kết hợp bài thuốc Quyên tý thang. Tap chí Y học Việt nam, 12 (1\&2), 222-226.

6. Bô Y tế (2016). Quyết đinh số 3465/QĐ-BYT ngày $8 / 7 / 2016$ về việc ban hành bộ mã danh mục dưng chung trong khám bệnh, chữa bệnh và thanh toán bảo hiểm y tế. Phu lục: Danh mục bênh theo ICD10, Hà Nội.

7. Viến $Y$ hoc cổ truyền Quân đôi (2013). Bênh tý. Một số chuyên đề nội khoa Ỳ học cổ truyền, NXB Quân đội nhân dân, Hà Nội, 240-273.

\section{ĐÁNH GIÁ CHẤT LƯợNG Bộ KÍT R\&D RT-qPCR HBV MộT BƯớC ĐİNH LƯỢ'NG PREGENOMIC RNA CỦA VI RÚT TRONG HUYẾT THANH BÊ̂NH NHÂN VIÊM GAN B MẠN TÍNH}

\section{TÓM TẮT}

Muc tiêu: Đánh giá chất lương bô kit R\&D RTqPCR HBV một bước để định lượng pgRNA trong huyết thanh bệnh nhân viêm gan vi rút $B$ mạn tính. Đối tượng và phương pháp nghiên cứu: Quy trình bao gồm việc đánh giá chất chỉ tiêu chất lượng như sau: ngưỡng phát hiện, ngưỡng định lượng, khoảng tuyến tính, độ chính xác, độ đặc hiểu, độ lăp lai và so sánh khả năng định lượng với phướng pháp RT-qPCR hai bước định lượng HBV-pgRNA. Kết quả: Ngưỡng phát hiện của bộ kit là $70 \mathrm{copy} / \mathrm{ml}$ huyết thanh và ngưỡng định lượng là $140 \mathrm{copy} / \mathrm{ml}$ huyết thanh. Khoảng tuyến tính là $10^{2}-10^{8} \mathrm{copy} / \mathrm{ml}$ với hệ số hồi quy là $\mathrm{R}^{2}=0,996$. Bộ kit RT-qPCR định lượing $\mathrm{HBV}$ pgRNA có độ chính xác cao $(\mathrm{CV} \leq 0,03)$, độ lặp lại tốt (deltaCt $<0,5$ ) và độ đặc hiệu $100 \%$. Hai bộ kit có sứ tương quan cao trong định lượng HBV-pgRiNA (Hệ số tuyến tính là $\left.R^{2}=0,9885\right)$. Kết luận: bộ kit $R \& D$ RTqPCR HBV một bước có thể sử dụng trong định lượng pgRNA huyết thanh và quản lý theo dõi bệnh nhân điều trị viêm gan $B$ man tính.

Tư khóa: Pregenomic RNA,bộ kit R\&D RT-qPCR HBV một bước, viêm gan B mạn tính

\section{SUMMARY}

EVALUATE THE QUALITY OF ONE-STEP RTqPCR HBV KIT TO DETECT THE SERUM PgRNA LEVEL IN CHRONIC HBV-INFECTED PATIENTS

Objective:This study was to evaluate the quality of one-step RT-qPCR HBV kit to detect the serum pgRNA level in chronic HBV-infected patients. Materials and methods: The limit of detection, the limit of quantitation, linear range, repeatability, precision, and specificity of one-step R\&D RT-qPCR HBV kit were included in the study, as well as

*Bênh viên Quân Y 103

Chịu trách nhiệm chính: Đỗ Như Bình

Email: nhubinh.do@vmmu.edu.vn

Ngày nhận bài: 29/4/2021

Ngày phản biện khoa học: 25/5/2021

Ngày duyệt bài: 15/6/2021 compared the capability with two-step RT-qPCR method to detect serum pgRNA level. Results: The limit of detection and the limit of quantitation were 70 copies $/ \mathrm{ml}$ and 140 copies $/ \mathrm{ml}$ of serum, respectively. The linear range was from $10^{2}$ to $10^{8} \mathrm{copies} / \mathrm{ml}, \mathrm{R}^{2}=$ 0,996 . The repeatability and precision of one-step R\&D RT-qPCR HBV kit were in good performan with $\mathrm{CV} \leq 0,03$, deltaCt $<0,5$, and specificity of $100 \%$. There was a high correlation in quantification of HBVpgRNA between the two kits $\left(R^{2}=0,9885\right)$. Conclusion: The one-step R\&D RT-qPCR HBV kit could be useful for detection of serum pgRNA level and follow-up management of treated chronic HBVinfected patients.

Keywords: Pregenomic RNA; one-step R\&D RTqPCR HBV kit; CHB

\section{I. ĐĂT VẤN ĐỀ}

HBV pgRNA (pregenomic RNA) - một trung gian trong quá trình nhân lên của HBV được thấy có măt trong huyết thanh ở bênh nhân VGBMT [3]. Trong quá trình điều trị, đặc biệt là điêuu trị bằng các thuốc NA, nồng độ HBV-pgRNA huyết thanh giảm từ từ song vẫn phát hiện được kéo dài, kể cả khi HBV DNA huyết thanh đã giảm xuống dưới ngưỡng phát hiện [4], [5].

Những nghiên cứu gân đây đã chỉ ra vai trò của HBV RNA huyết thanh: phản ánh khả năng kháng vi rút của các thuốc NA; là yếu tố dư đoán sớm sự xuất hiên đột biến kháng thuốc trong quá trình điều trị bằng lamivudine; dự đoán độc lập đáp ứng vi rút học ban đâu hoặc ức chế HBV sớm hơn trong quá trình điêu trị bằng các thuốc NA; dự đoán sự tái hoạt động HBV sau khi ngừng sử dụng các thuốc NA [6]. Chính vì vậy, HBV-pgRNA huyết thanh có thể đóng vai trò quan trọng trong đánh giá, theo dõi và tối ưu hóa hiệu quả điêu trị ở bênh nhân VGBMT [4], [6], [8].

Ở Việt Nam, cho đến thời điểm hiện nay, việc định lượng HBV-pgRNA huyết thanh cũng như 